\title{
Subinhibitory concentrations of silver nanoparticles and silver nitrate on the adaptative and cross-resistance to antibiotics on bovine mastitis pathogens
}

\author{
Patrícia Érica Fernandes ${ }^{1}$ (D) Roberta Barbosa Teodoro Alves ${ }^{2}$ Natan de Jesus Pimentel-Filho ${ }^{3}$ (D)

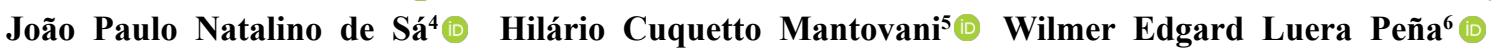 \\ Nélio José de Andrade ${ }^{* *}$ (i)
}

${ }^{1}$ Departamento Acadêmico, Instituto Federal de Educação, Ciência e Tecnologia de Alagoas (IFAL), Campus Batalha, Batalha, AL, Brasil. ${ }^{2}$ Departamento Acadêmico, Instituto Federal de Educação, Ciência e Tecnologia de Alagoas (IFAL), Campus Piranhas, Piranhas, AL, Brasil. ${ }^{3}$ Centro de Ciências da Natureza, Universidade Federal de São Carlos (UFSCar), Campus Lagoa do Sino, Buri, SP, Brasil.

${ }^{4}$ Núcleo de Agroindústria, Universidade Federal de Sergipe (UFS), Campus Sertão, Nossa Senhora da Glória, SE, Brasil

${ }^{5}$ Departamento de Microbiologia, Universidade Federal de Viçosa (UFV), Viçosa, MG, Brasil.

${ }^{6}$ Departamento de Tecnologia de Alimentos, Universidade Federal de Viçosa (UFV), 36570-000, Viçosa, MG, Brasil. E-mail: nandrade@ufv.br. ${ }^{*}$ Corresponding author.

\begin{abstract}
Biocides and/or antibiotics used in subinhibitory concentrations can promote the development of adaptive resistance or even cross-resistance in microorganisms. However, studies on these responses following silver treatments are scarce in the literature. Silver-based compounds, including silver nanoparticles (Ag-NPS), can be an alternative in the prevention and treatment of bovine mastitis. Thus, this research evaluated the effect of subinhibitory dosages of $\mathrm{Ag}-\mathrm{NPs}$ and $\mathrm{Ag}^{+}$ions from silver nitrate $\left(\mathrm{AgNO}_{3}\right)$ on Staphylococcus aureus and Escherichia coli isolated from milk of cows with mastitis. Ag-NPs were synthesized by chemical reduction using $\mathrm{AgNO}_{3}$ and sodium citrate and the minimum inhibitory concentration (MIC) of $\mathrm{Ag}$-NPS and $\mathrm{Ag}^{+}$ions on the mastitis pathogens were determined. Isolates were exposed to subinhibitory concentrations of Ag-NPs or $\mathrm{AgNO}_{3}$ for 10 consecutive days to verify the development of adaptive resistance evaluated by changes in the MIC values. The development of cross-resistance with antibiotics was also studied, being verified by comparing the sensitivity profile of treated cells with non-treated cells. AgNO $\mathrm{A}_{3}$ was more effective against all isolates. There was no change in the MIC values or in the antibiotic sensitivity profile for both bacteria following consecutive exposure to subinhibitory dosages of Ag-NPs or $A g N O_{3}$, indicating that silver was not able to select adaptive resistance or cross resistance to the tested antibiotics. The potential of silver presented by these results is favorable to the continuity of studies aiming to elaborate silver-based therapies for the treatment of bovine mastitis. Key words: adaptive resistance, antibiotics, microbial resistance, Staphylococcus aureus, Escherichia coli.
\end{abstract}

Concentrações subinibitórias de nanopartículas de prata e nitrato de prata na resistência adaptativa e cruzada com antibióticos em patógenos de mastite bovina

RESUMO: Biocidas elou antibióticos em concentrações sub-inibitórias podem promover o desenvolvimento de resistência adaptativa ou mesmo resistência cruzada nos micro-organismos. Entretanto, estudos destas respostas após o tratamento com a prata são escassos na literatura. Compostos a base de prata, incluindo as nanopartículas de prata (Ag-NPs), podem ser uma alternativa na prevenção elou tratamento de mastite bovina. Assim, este trabalho objetivou determinar o efeito de doses sub-inibitórias de Ag-NPs e dos ions Ag ${ }^{+}$provenientes do nitrato de prata $\left(\mathrm{AgNO}_{3}\right)$ sobre isolados de Staphylococcus aureus e de Escherichia coli, provenientes de leite de vacas com mastite. As Ag-NPs foram sintetizadas por redução química utilizando $\mathrm{AgNO}_{3}$ e citrato de sódio e a Concentração Mínima Inibitória (CMI) das Ag-NPs e ions $\mathrm{Ag}^{+}$nos patógenos da mastite foi determinada. Os isolados foram expostos a concentrações sub-inibitórias de $\mathrm{Ag}$-NPs ou de $\mathrm{AgNO}{ }_{3}$ por 10 dias consecutivos para verificar o desenvolvimento de resistência adaptativa à prata pela mudança no valor da CMI, e de resistência cruzada com antibióticos pela mudança no perfil de sensibilidade em relação ao controle. AgNO apresentou-se mais efetivo contra todos os isolados. Não foi verificada alteração no valor da CMI nem do perfil de sensibilidade aos antibióticos, indicando que não houve seleção de resistência adaptativa à prata e de resistência cruzada aos antibióticos pelos micro-organismos estudados. O uso potencial da prata apresentado nos resultados é favorável à continuidade dos estudos objetivando a elaboração de terapias à base de prata para o tratamento da mastite bovina. Palavras-chave: resistência adaptativa, antibióticos, resistência microbiana, Staphylococcus aureus, Escherichia coli.

\section{INTRODUCTION}

Mastitis, the inflammatory process of the mammary gland, is an important disease in dairy cattle and is characterized by decreased production and changes in the composition of milk (WANG et al., 2017), causing great losses to farmers and industries. In general, it is caused by infectious agents such as algae, yeast, mycoplasmas and, mainly, bacteria (SANKAR, 2016). The main treatment for mastitis is antibiotic therapy; however, this method has some limitations due to the increased occurrence 
of microbial resistance and possible presence of antibiotic residues in the milk, which is a serious public health problem. Therefore, alternative to antibiotics in the treatment of bovine mastitis have been suggested, including the use of nanoparticles, vaccines, bacteriophages, medicinal plants and bacteriocin (SANKAR, 2016; MUSHTAQ et al., 2018; LASAGNO et al., 2019; ALGHARIB et al., 2020).

Some microorganisms are naturally resistant to certain antimicrobial agents, while others can develop mechanisms to protect themselves, such as adaptive resistance (GALÁN et al., 2013). Adaptive resistance occurs due to the microorganism's ability to adapt and modify its phenotype to develop resistance to certain stressors. It is characterized by an increase in bacterial resistance to inhibitory or lethal doses of an antimicrobial agent due to pre-exposure to a subinhibitory concentration that does not inhibit bacterial growth, but can activate certain mechanisms, resulting in greater resistance to this antimicrobial agent (PATEL \& LEVITIN, 2014). Cross-resistance is another microbial response that happens when microorganisms pre-exposed to subinhibitory dosages of a single biocide become resistant to many other structurally and functionally unrelated antimicrobials (MAVRI \& SMOLE MOŽINA, 2013).

Silver-containing compounds have been used for years due to their antimicrobial properties, and were widely used before the introduction of antibiotics in the early $20^{\text {th }}$ century (MIRSATTARI et al., 2004). According to PAL et al. (2007), silver attacks microbial cells by multiple mechanisms, making them difficult to develop resistance, compared to conventional antibiotics that generally exert their antimicrobial effect at a specific target. According to these authors, microorganisms would only protect themselves from silver if they were able to develop multiple mutations simultaneously. In recent years, silver nanoparticles (Ag-NPs) have emerged as the most used antimicrobial nanomaterial in various consumer products such as textiles, personal care products, medical devices, dental and wound healing applications (EDWARDS-JONES, 2009; BALLOTTIN et al., 2017; BURDUȘEL et al., 2018). Thus, silver-based compounds, such as Ag-NPs, can be used as a relevant alternative in the prevention and/or treatment for bovine mastitis.

There are several studies in the literature reporting the effect of subinhibitory dosages of antibiotics and other biocides on the development of microbial resistance (OTTO et al., 2013; KUMARI et al., 2014; ROCH et al., 2014; BENGTSSON-PALME \& LARSSON, 2016); however, studies on the effect of subinhibitory dosages of silver on this physiological response are scarce in the literature. In this context, the objective of this research evaluated the antimicrobial activity and development of adaptive and crossresistance induced by subinhibitory concentrations of Ag-NPs and $\mathrm{AgNO}_{3}$ in $S$. aureus and E. coli isolated from bovine mastitis.

\section{MATERIALS AND METHODS}

\section{Antimicrobial agents}

The Ag-NPs used in this study were synthesized by chemical reduction of silver nitrate $\left(\mathrm{AgNO}_{3}\right)$ (Sigma-Aldrich, USA) with sodium citrate (Sigma-Aldrich, USA), as previously described by Monteiro et al. 2009, with minor modifications. The synthesized Ag-NPs were characterized by UV-vis spectroscopy in a wavelength ranging from 290 to 700 $\mathrm{nm}$ using a quartz cuvette with $10 \mathrm{~mm}$ optical path (spectrophotometer model UV-1601 PC Shimadzu, Japan), transmission electron microscopy (TEM) (FEI Tecnai G2-20 SuperTwin, USA), dynamic light scattering (DLS) and zeta potential $(\zeta)$ (Zetasizer Nano ZS, Malvern Instruments, UK).

The antibiotic disks were purchased from Cefar (São Paulo, Brazil). The following antibiotics were used for $S$. aureus: cephalexin $30 \mu \mathrm{g}$ (CFE), tetracycline $30 \mu \mathrm{g}$ (TET), streptomycin $10 \mu \mathrm{g}$ (EST), gentamicin $10 \mu \mathrm{g}(\mathrm{GEN})$, ciprofloxacin $5 \mu \mathrm{g}$ (CIP), and norfloxacin $10 \mu \mathrm{g}$ (NOR) (SAEKI et al., 2011). For E. coli, ampicillin $10 \mu \mathrm{g}$ (AMP), cephalexin 30 $\mu \mathrm{g}$ (CFE), ceftiofur $30 \mu \mathrm{g}(\mathrm{CTF})$, enrofloxacin $5 \mu \mathrm{g}$ (ENO), gentamicin $10 \mu \mathrm{g}(\mathrm{GEN})$ and cotrimoxazole $25 \mu \mathrm{g}$ (SUT) were used as suggested for the treatment of environmental mastitis (COSTA et al., 2014).

\section{Bacterial strains and culture conditions}

Experiments were carried out on eight $S$. aureus isolates obtained from the Mastitis Pathogens Culture Collection, maintained at Embrapa Dairy Cattle Research Center (Juiz de Fora, Minas Gerais, Brazil) and eight E. coli, belonging to the Bacterial Diseases Laboratory of the Veterinary Department of the Federal University of Viçosa (Viçosa, Minas Gerais, Brazil), all of them isolated from milk of cows with clinical mastitis. Stock cultures were kept at -80 ${ }^{\circ} \mathrm{C}$ in microtubes containing Brain Heart Infusion broth (BHI) (Himedia, India) added of $20 \%$ glycerol. Before tests, all isolates were grown twice in $\mathrm{BHI}$ at $37{ }^{\circ} \mathrm{C}$ for $18 \mathrm{~h}$. Then, the bacterial suspensions were centrifuged at $4000 \mathrm{x} g$ for $5 \mathrm{~min}$ at $4{ }^{\circ} \mathrm{C}$. The supernatant was discarded and the cells were washed twice in $10 \mathrm{~mL} 0.85 \% \mathrm{~m} \cdot \mathrm{v}^{-1}$ saline solution. The inoculum was prepared by directly suspending the 
obtained pellet in saline solution. The absorbance was adjusted to the range of 0.08 to 0.10 at $625 \mathrm{~nm}$ using a spectrophotometer (Kazuaki IL227, China), which corresponds to the McFarland standard of 0.5 , which contains approximately $1.0 \times 10^{8} \mathrm{CFU} \cdot \mathrm{ml}^{-1}$.

\section{Minimum Inhibitory Concentration (MIC)}

The MIC of Ag-NPs and $\mathrm{AgNO}_{3}$ on the mastitis isolates was determined by broth microdilution test according to the methodology proposed by the Clinical and Laboratory Standards Institute (CLSI, 2003). For this purpose, serial dilutions ranging from 50 to $0.098 \mu \mathrm{g} \cdot \mathrm{ml}^{-1}$ of $\mathrm{Ag}$ $\mathrm{NPs}$ or $\mathrm{AgNO}_{3}$ were made in Müller-Hinton broth (Himedia, India) in 96-wells polystyrene microtiter plates. Bacterial inoculum was prepared as previously described in order to obtain an initial concentration of approximately $5.0 \times 10^{5} \mathrm{CFU} \cdot \mathrm{ml}^{-1}$ in each well. Plates were incubated in an automatic microplate reader (Multiskan GO 1510, Thermo Scientific, Finland) at 37 ${ }^{\circ} \mathrm{C}$ for $18 \mathrm{~h}$, with reading every $60 \mathrm{~min}$. The MIC was determined as the lowest concentration in which there was no microbial growth after $18 \mathrm{~h}$ of incubation.

\section{Adaptive resistance}

Experiments were performed according to SANTANA et al. (2012), with minor modifications. To verify the development of adaptive resistance to Ag-NPs and $\mathrm{AgNO}_{3}$, the bacteria were transferred 10 times, after incubation at $37^{\circ} \mathrm{C}$ for $24 \mathrm{~h}$, in Müller-Hinton broth supplemented with $\mathrm{Ag}-\mathrm{NPs}$ or $\mathrm{AgNO}_{3}$ in subinhibitory concentration $(0.25 \mathrm{x}$ MIC). The same procedure was performed in Müller-Hinton broth without antimicrobials (control). After this procedure, bacteria adapted with Ag-NPs or $\mathrm{AgNO}_{3}$ in subinhibitory dosages and nonadapted cells (control), were exposed to the previous inhibitory concentrations of these antimicrobials (MIC values) and growth was monitored by reading the optical density at $600 \mathrm{~nm}$, at every $60 \mathrm{~min}$, during $18 \mathrm{~h}$ at 37 ${ }^{\circ} \mathrm{C}$. Results obtained were compared to the previously performed with cells not exposed to subinhibitory dosages of Ag-NPs or $\mathrm{AgNO}_{3}$.

\section{Determination of cross-resistance with antibiotics}

To verify the development of crossresistance with antibiotics, the antibiogram was performed with cells adapted to subinhibitory dosages of Ag-NPs or $\mathrm{AgNO}_{3}$ and cells not adapted (control). For this experiment, four isolates of $S$. aureus and four of $E$. coli were randomly selected. After pre-exposure of the bacteria for 10 consecutive days, in Müller-Hinton broth supplemented with Ag$\mathrm{NPs}$ or $\mathrm{AgNO}_{3}$ at subinhibitory concentration $(0.25 \mathrm{x}$
MIC), disk-diffusion sensitivity test was performed according to (CLSI, 2015) with adapted and nonadapted cells to verify changes in the antibiotic sensitivity profile. After sterilization at $121{ }^{\circ} \mathrm{C}$ for 15 min, Müeller-Hinton agar (Himedia, India) was cooled to $45^{\circ} \mathrm{C}$ and $25 \mathrm{~mL}$ were distributed in $90 \mathrm{~mm}$ diameter Petri dishes, to ensure a uniform depth of approximately $4 \mathrm{~mm}$. Bacterial inoculum, prepared as previously described, was spread on the agar surface and then, $6.35 \mathrm{~mm}$ diameter discs impregnated with the antibiotics were placed on the agar. Plates were incubated at $37{ }^{\circ} \mathrm{C}$ for $18 \mathrm{~h}$ and the inhibition halos were determined using a millimeter rule. The bacteria were classified as sensitive (S) or resistant (R) to antibiotics, before and after the adaptation treatment according to the Sensifar and Multifar-cefar ${ }^{\circledR}$ manual.

\section{Data analysis}

The results of the halo sizes were subjected to analysis of variance (ANOVA), and the means compared by Tukey test at 5\% probability. Statistical analyses were performed in the Statistical Analysis System (SAS Institute, North Carolina, USA), version 9.1, licensed to Federal University of Viçosa.

\section{RESULTS AND DISCUSSION}

The dispersion of synthesized Ag-NPs presented typical surface plasmon resonance with a peak at $418 \pm 3,2 \mathrm{~nm}$ confirming their formation (Figure 1A). The images observed by TEM (Figure 1B) revealed that the Ag-NPs are approximately spherical with size around $5 \mathrm{~nm}$. The mean size determined by DLS and the $\zeta$ potential of Ag-NPs was $3.4 \pm 1.2$ and $-31.9 \pm 8.6 \mathrm{mV}$, respectively.

Despite the high level of astigmatisms and low contrast of the TEM image, the presence of nanoparticulate material in the sample can be observed. These findings are supported by the results of DLS and the UV-vis peak, which is compatible with the silver nanoparticle plasmon resonance

The MIC value of Ag-NPs was $50 \mu \mathrm{g} \cdot \mathrm{ml}^{-1}$ for all eight $S$. aureus isolates and $25 \mu \mathrm{g} \cdot \mathrm{ml}^{-1}$ for all eight $E$. coli isolates. Other studies have also reported greater efficiency of Ag-NPs against gram-negative bacteria than gram-positive, associated with the structural difference in the cell wall between these two groups of bacteria (KIM et al., 2007; VU et al., 2018). In a study conducted by FAYAZ et al. (2009) the MIC value was $80 \mu \mathrm{g} \cdot \mathrm{ml}^{-1}$ and $65 \mu \mathrm{g} \cdot \mathrm{ml}^{-1}$ for the gram-positive bacteria $S$. aureus and Micrococcus luteus, respectively, whereas the MIC was $30 \mu \mathrm{g} \cdot \mathrm{ml}^{-1}$ and $35 \mu \mathrm{g} \cdot \mathrm{ml}^{-1}$ for E. coli and Salmonella Typhi, 


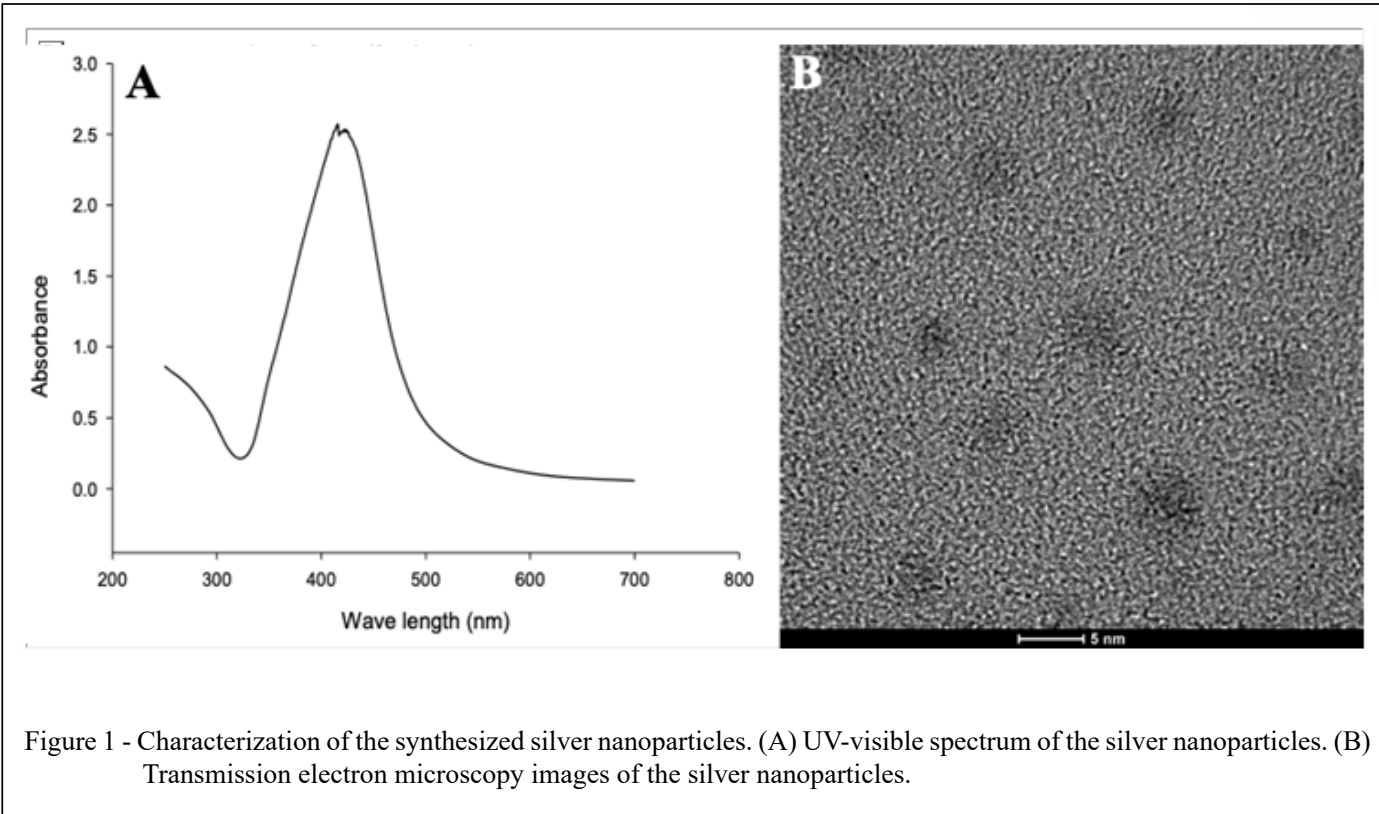

respectively. The result highlighted the antimicrobial potential of Ag-NPs against $E$. coli since based in their major resistance in comparison with grampositive bacteria, considering their cellular envelope differences, several strategies have been used on the gram-negative bacteria control (BREIJYEH et al., 2020). The MIC of $\mathrm{AgNO}_{3}$ was $12.5 \mu \mathrm{g} \cdot \mathrm{ml}^{-1}$ for both bacterial species. In a study performed by XIU et al. (2011), a greater efficiency of $\mathrm{AgNO}_{3}$ in relation to Ag-NPs was observed against E. coli. These authors have attributed the higher toxicity of $\mathrm{AgNO}_{3}$ in comparison with Ag-NPs to the greater bioavailability and potential for uptake of $\mathrm{Ag}^{+}$ions of the salt.

After adaptation of $S$. aureus and $E$. coli isolates following consecutive exposition to subinhibitory dosages of Ag-NPs or $\mathrm{AgNO}_{3}$, the development of resistance to silver was evaluated by assessing changes in the MIC values. The adapted cells of $S$. aureus and E. coli did not grow when they were exposed to the previous inhibitory dosages of the antimicrobials (MIC) at $37{ }^{\circ} \mathrm{C}$ for $18 \mathrm{~h}$, indicating that both species did not develop adaptive resistance to silver.

As presented in table 1, all $S$. aureus isolates were sensitive to the tested antibiotics, before and after the adaptation treatment with subinhibitory dosages of the antimicrobials, except for the isolates 4051 and 4075 , which were resistant to tetracycline before and after adaptation. Resistance to tetracycline by $S$. aureus isolates has been reported in the literature. COSTA et al. (2013) reported variation in the resistance profile of $S$. aureus exposed to some products routinely used in the treatment of bovine mastitis, including tetracycline. In a study by CARVALHO et al. (2018), 33.33\% of $S$. aureus isolated from raw milk were resistant, $44,44 \%$ sensitive and $22.22 \%$ showed intermediate resistance to tetracycline.

There was as a significant reduction $(P<$ $0.05)$ in the diameter of the inhibition halo of isolate 4236 following adaptation to $\mathrm{AgNO}_{3}$; however, this reduction was not sufficient to change the sensitivity profile of that bacterial isolate to the antibiotic, maintaining the status of sensitive (Table 1). Therefore, it is important to note that there was no change in the sensitivity profile of $S$. aureus isolates to the antibiotics tested after exposure to subinhibitory dosages of Ag-NPs or $\mathrm{AgNO}_{3}$, indicating that these isolates did not develop cross-resistance to the tested antibiotics.

In a research carried out by BEHIRY et al. (2012), S. aureus strains isolated from bovine mastitis were exposed to subinhibitory concentrations of commercial disinfectants based on chlorhexidine digluconate or nonoxynol-9 iodide complex (iodophor), used in the cleaning of the ceilings. The authors observed that the majority of the isolates (90 \%) developed resistance (increased MIC) to iodophor, after ten repeated passes in subinhibitory concentrations of this antimicrobial. However, only 
Table 1 - Diameter of the inhibition zone ( $\mathrm{mm}$ ) and standard deviation of non-adapted Staphylococcus aureus isolates (Control) and adapted to subinhibitory doses of silver nanoparticles (Ag-NPs) and silver nitrate $\left(\mathrm{AgNO}_{3}\right)$, profile of sensitivity (P), being sensitive (S) or Resistant (R).

\begin{tabular}{lllllllllll}
\hline & & & & & & \\
\hline
\end{tabular}

CEF: cephalexin $(30 \mu \mathrm{g})$; TET: Tetracycline $(30 \mu \mathrm{g})$; EST: Streptomycin $(10 \mu \mathrm{g})$; GEN: gentamicin (10 $\mu \mathrm{g})$; CIP: ciprofloxacin $(5 \mu \mathrm{g})$; NOR: Norfloxacin $(10 \mu \mathrm{g})$. Same letters in the same column do not differ statistically at the 5\% level by the Tukey test.

No classification established in the reference manual.

one isolate developed resistance to chlorhexidine digluconate. They also did not observe the development of simultaneous resistance to antibiotics.

All E. coli isolates were sensitive to the antibiotics tested before and after the adaptation treatment and there was no statistical difference $(P>0.05)$ in the size of the halos (Table 2). In a study conducted by COSTA et al. (2014), a high sensitivity of $E$. coli isolates from mastitis to the same antibiotics was also observed. As observed for $S$. aureus, all $E$. coli isolates did not develop cross-resistance to antibiotics after adaptation in subinhibitory dosages of $\mathrm{Ag}$-NPs or $\mathrm{AgNO}_{3}$, as there was no change in the sensitivity profile in comparison to the control. Similar results were reported by OLIVEIRA et al. (2017), in which the adaptation of bacteria to subinhibitory concentration of resveratrol did not promote the development of homologous resistance to resveratrol or cross-resistance with benzalkonium chloride or with the tested antibiotics.

In a study conducted by CAPITA et al. (2014), it was reported that the adaptation of $E$. coli ATCC 12806 to subinhibitory concentrations of trisodium phosphate, sodium nitrite and sodium hypochlorite promoted the development of acquired resistance to such biocides, in addition to reducing sensitivity to a range of antibiotics, especially, aminoglycosides, cephalosporins and quinolones, in relation to unexposed cells. Sodium nitrite caused a greater increase in cross-resistance compared to sodium hypochlorite and trisodium phosphate. These results showed that the use of these antimicrobials in subinhibitory concentrations can represent a serious public health problem, which did not occur with the use of Ag-NPs or $\mathrm{AgNO}_{3}$. However, it is important to highlight that since the development of resistance may vary among different species as well as among different serotypes of the same species, tests including other bacterial species and other strains should be performed, as suggested by SOUMET et al. (2016).

\section{CONCLUSION}

The silver nanoparticles (Ag-NPs) synthesized in this research were more effective against $\boldsymbol{E}$. coli than $\boldsymbol{S}$. aureus. Conversely, silver nitrate $\left(\mathrm{AgNO}_{3}\right)$ showed a similar effect against the two bacterial species studied, with lower MIC value compared to Ag-NPs. The adaptation of $S$. aureus and $E$. coli isolates to subinhibitory concentrations of Ag-NPs or $\mathrm{AgNO}_{3}$ for 10 consecutive days did not promote the adaptative resistance to silver or crossresistance to antibiotics as there was no change in the 
Table 2 - Diameter of the inhibition zone ( $\mathrm{mm}$ ) and standard deviation of non-adapted Escherichia coli isolates (Control) and adapted to subinhibitory doses of silver nanoparticles (Ag-NPs) and silver nitrate $\left(\mathrm{AgNO}_{3}\right)$, profile of sensitivity $(\mathrm{P})$, being sensitive $(\mathrm{S})$ or Resistant (R).

\begin{tabular}{|c|c|c|c|c|c|c|c|c|c|c|c|c|}
\hline Isolates & AMP $10 \mu \mathrm{g}$ & $\mathrm{P}$ & CEF $30 \mu \mathrm{g}$ & $\mathrm{P}$ & CTF $30 \mu \mathrm{g}$ & $\mathrm{P}$ & SUT $25 \mu \mathrm{g}$ & $\mathrm{P}$ & ENO $5 \mu \mathrm{g}$ & $\mathrm{P}$ & GEN $10 \mu \mathrm{g}$ & $\mathrm{P}$ \\
\hline \multicolumn{13}{|c|}{ 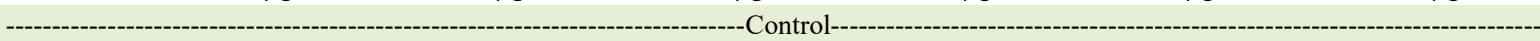 } \\
\hline 1 & $23.0 \pm 1.0^{\mathrm{a}}$ & $\mathrm{S}$ & $23.7 \pm 2.2^{\mathrm{a}}$ & $\mathrm{S}$ & $28.0 \pm 2.0^{\mathrm{a}}$ & $\mathrm{S}$ & $27.0 \pm 3.0^{\mathrm{a}}$ & $\mathrm{S}$ & $29.0 \pm 3.0^{\mathrm{a}}$ & $\mathrm{S}$ & $18.0 \pm 1.0^{\mathrm{a}}$ & $\mathrm{S}$ \\
\hline 7 & $21.0 \pm 3.0^{\mathrm{a}}$ & $\mathrm{S}$ & $20.2 \pm 1.9^{\mathrm{a}}$ & $\mathrm{S}$ & $27.7 \pm 3.0^{\mathrm{a}}$ & $\mathrm{S}$ & $27.0 \pm 3.0^{\mathrm{a}}$ & $\mathrm{S}$ & $31.0 \pm 1.0^{\mathrm{a}}$ & $\mathrm{S}$ & $19.0 \pm 1.0^{\mathrm{a}}$ & $\mathrm{S}$ \\
\hline 19 & $20.0 \pm 2.0^{\mathrm{a}}$ & $\mathrm{S}$ & $21.8 \pm 2.1^{\mathrm{a}}$ & $\mathrm{S}$ & $29.0 \pm 1.1^{\mathrm{a}}$ & $\mathrm{S}$ & $27.0 \pm 1.0^{\mathrm{a}}$ & S & $29.0 \pm 1.0^{\mathrm{a}}$ & $\mathrm{S}$ & $20.0 \pm 1.0^{\mathrm{a}}$ & $\mathrm{S}$ \\
\hline 23 & $25.0 \pm 1.0^{\mathrm{a}}$ & $\mathrm{S}$ & $22.5 \pm 0.7^{\mathrm{a}}$ & $\mathrm{S}$ & $28.5 \pm 2.1^{\mathrm{a}}$ & $\mathrm{S}$ & $26.0 \pm 1.0^{\mathrm{a}}$ & $\mathrm{S}$ & $31.0 \pm 2.0^{\mathrm{a}}$ & $\mathrm{S}$ & $19.0 \pm 1.0^{\mathrm{a}}$ & $\mathrm{S}$ \\
\hline \multicolumn{13}{|c|}{--1- } \\
\hline 1 & $24.0 \pm 2.0^{\mathrm{a}}$ & $\mathrm{S}$ & $25.0 \pm 1.0^{\mathrm{a}}$ & $\mathrm{S}$ & $28.0 \pm 2.0^{a}$ & $\mathrm{~S}$ & $26.8 \pm 3.3^{a}$ & $\mathrm{~S}$ & $30.0 \pm 1.0^{a}$ & $\mathrm{~S}$ & $18.0 \pm 2.0^{\mathrm{a}}$ & $\mathrm{S}$ \\
\hline 7 & $20.0 \pm 3.0^{\mathrm{a}}$ & $\mathrm{S}$ & $22.0 \pm 1.0^{\mathrm{a}}$ & $\mathrm{S}$ & $25.0 \pm 2.0^{\mathrm{a}}$ & $\mathrm{S}$ & $25.5 \pm 3.0^{\mathrm{a}}$ & $\mathrm{S}$ & $31.0 \pm 1.0^{\mathrm{a}}$ & $\mathrm{S}$ & $18.0 \pm 1.0^{\mathrm{a}}$ & $\mathrm{S}$ \\
\hline 19 & $21.0 \pm 1.0^{\mathrm{a}}$ & $\mathrm{S}$ & $24.0 \pm 4.0^{\mathrm{a}}$ & $\mathrm{S}$ & $29.0 \pm 1.0^{\mathrm{a}}$ & $\mathrm{S}$ & $27.3 \pm 1.8^{a}$ & $\mathrm{~S}$ & $31.0 \pm 1.0^{\mathrm{a}}$ & $\mathrm{S}$ & $21.0 \pm 1.0^{\mathrm{a}}$ & $\mathrm{S}$ \\
\hline 23 & $25.0 \pm 2.0^{\mathrm{a}}$ & $\mathrm{S}$ & $25.0 \pm 1.0^{\mathrm{a}}$ & $\mathrm{S}$ & $28.0 \pm 3.0^{\mathrm{a}}$ & $\mathrm{S}$ & $27.8 \pm 2.3^{\mathrm{a}}$ & $\mathrm{S}$ & $31.0 \pm 2.0^{\mathrm{a}}$ & $\mathrm{S}$ & $20.0 \pm 2.0^{\mathrm{a}}$ & $\mathrm{S}$ \\
\hline \multicolumn{13}{|c|}{ 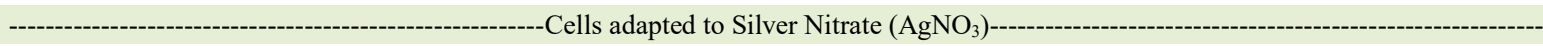 } \\
\hline 1 & $23.0 \pm 2.0^{\mathrm{a}}$ & $\mathrm{S}$ & $23.0 \pm 2.0^{\mathrm{a}}$ & $\mathrm{S}$ & $29.0 \pm 1.0^{\mathrm{a}}$ & $\mathrm{S}$ & $30.0 \pm 1.0^{\mathrm{a}}$ & $\mathrm{S}$ & $33.0 \pm 2.0^{\mathrm{a}}$ & $\mathrm{S}$ & $20.0 \pm 0.0^{\mathrm{a}}$ & $\mathrm{S}$ \\
\hline 7 & $21.0 \pm 4.0^{\mathrm{a}}$ & $\mathrm{S}$ & $20.0 \pm 2.0^{\mathrm{a}}$ & $\mathrm{S}$ & $25.0 \pm 6.0^{\mathrm{a}}$ & $\mathrm{S}$ & $26.0 \pm 1.0^{\mathrm{a}}$ & $\mathrm{S}$ & $32.0 \pm 2.0^{\mathrm{a}}$ & $\mathrm{S}$ & $18.0 \pm 1.0^{\mathrm{a}}$ & $\mathrm{S}$ \\
\hline 19 & $21.0 \pm 2.0^{\mathrm{a}}$ & $\mathrm{S}$ & $22.0 \pm 2.0^{\mathrm{a}}$ & $\mathrm{S}$ & $28.0 \pm 1.0^{\mathrm{a}}$ & $\mathrm{S}$ & $28.0 \pm 0.0^{\mathrm{a}}$ & $\mathrm{S}$ & $28.0 \pm 3.0^{\mathrm{a}}$ & $\mathrm{S}$ & $19.0 \pm 2.0^{\mathrm{a}}$ & $\mathrm{S}$ \\
\hline 23 & $24.0 \pm 1.0^{\mathrm{a}}$ & $\mathrm{S}$ & $23.0 \pm 1.0^{\mathrm{a}}$ & S & $30.0 \pm 2.0^{\mathrm{a}}$ & S & $27.0 \pm 2.0^{\mathrm{a}}$ & $\mathrm{S}$ & $33.0 \pm 1.0^{\mathrm{a}}$ & $\mathrm{S}$ & $19.0 \pm 1.0^{\mathrm{a}}$ & S \\
\hline
\end{tabular}

AMP: ampicillin; CEF: cephalexin; CTF: ceftiofur; SUT: cotrimoxazole; ENO: enrofloxacin; GEN: gentamicina.

Same letters in the same column do not differ statistically at the $5 \%$ level by the Tukey test.

MIC values or in the sensitivity profile of the isolates to the tested antibiotics, in relation to the control.

These results reinforce the potential use of silver on the mastitis-associated bacteria. Further experiments should be performed in order to evaluate the effect of silver nanoparticles (Ag-NPs) and Ag+ ions in loco against mastitis disease. Also, combined effect of the Ag-NPs with other antimicrobials would amplify treatment possibilities.

\section{ACKNOWLEDGEMENTS}

The authors acknowledge the Conselho Nacional de Desenvolvimento Científico e Tecnológico (CNPq/Brasil), Coordenação de Aperfeiçoamento de Pessoal de Nível Superior (CAPES/Brasil) and Fundação de Amparo à Pesquisa de Minas Gerais (Fapemig) for financial support. Authors thank also the Bacterial Diseases Laboratory of the Veterinary Department of the Federal University of Viçosa and the Embrapa Dairy Cattle Research Center (Juiz de Fora, Minas Gerais, Brazil) for providing the mastitis isolates, and the Center of Microscopy of the Federal University of Minas Gerais (http://www.microscopia.ufmg.br) for providing the equipment and technical support for experiments involving electron microscopy.

\section{DECLARATION OF CONFLICT OF INTERESTS}

The authors declare no conflict of interest. The founding sponsors had no role in the design of the study; in the collection, analyses, or interpretation of data; in the writing of the manuscript, and in the decision to publish the results. We have no conflict of interest to declare.

\section{AUTHORS 'CONTRIBUTIONS}

All authors contributed to the design and writing of the manuscript. All authors critically reviewed the manuscript and approved the final version.

\section{REFERENCES}

ALGHARIB, S. A.; DAWOOD, A.; XIE, S. Nanoparticles for treatment of bovine Staphylococcus aureus mastitis. Drug Delivery, v.27, n.1, p.292-308, 2020. Available from: <https:// www.ncbi.nlm.nih.gov/pmc/articles/PMC7034104/>. Accessed: Jun. 12, 2020. doi: 10.1080/10717544.2020.1724209.

BALLOTTIN, D. et al. Antimicrobial textiles: Biogenic silver nanoparticles against Candida and Xanthomonas. Materials Science and Engineering C, v.75, p.582-589, 2017. Available from: $\quad<$ https://www.sciencedirect.com/science/article/abs/pii/ S0928493116320070>. Accessed: Jun. 12, 2020. doi: 10.1016/j. msec.2017.02.110.

BEHIRY, A. EL et al. In vitro susceptibility of Staphylococcus aureus strains isolated from cows with subclinical mastitis to different antimicrobial agents. Journal of Veterinary Science, v.13, n.2, p.153-161, 2012. Available from: <https://www.ncbi. nlm.nih.gov/pmc/articles/PMC3386340/pdf/jvs-13-153.pdf > Accessed: Apr. 3, 2020. doi: 10.4142/jvs.2012.13.2.153. 
BENGTSSON-PALME, J.; LARSSON, D. G. J. Concentrations of antibiotics predicted to select for resistant bacteria: Proposed limits for environmental regulation. Environment International, v.86, p.140-149, 2016. Available from: <file://C:/Users/55319/ Downloads/1-s2.0-S0160412015300817-main.pdf>. Accessed: Apr. 6, 2020. doi: 10.1016/j.envint.2015.10.015.

BREIJYEH, Z. et al.,. Resistance of gram-negative bacteria to current antibacterial agents and approaches to resolve it. Molecules, v.25, n.6, 2020. Available from: <https:/www.ncbi. nlm.nih.gov/pmc/articles/PMC7144564/>. Accessed: Apr. 27, 2020. doi: 10.3390/molecules 25061340 .

BURDUȘEL, A. C. et al. Biomedical applications of silver nanoparticles: An up-to-date overview. Nanomaterials, v.8, n.9, p.1-25, 2018. Available from: <https://pubmed.ncbi.nlm. nih.gov/30200373/>. Accessed: Jun. 12, 2020. doi: 10.3390/ nano8090681.

CAPITA, R. et al. Exposure of Escherichia coli ATCC 12806 to sublethal concentrations of food-grade biocides influences its ability to form biofilm, resistance to antimicrobials, and ultrastructure. Applied and Environmental Microbiology, v.80, n.4, p.1268-1280, 2014. Available from: <https://www.ncbi.nlm. nih.gov/pmc/articles/PMC3911067/>. Accessed: Apr. 1, 2020. doi: 10.1128/AEM.02283-13.

Clinical and Laboratory Standards Institute (CLSI) (2003) Metodologia dos Testes de Sensibilidade a Agentes Antimicrobianos por Diluição para Bactéria de Crescimento Aeróbico : Norma Aprovada - Sexta Edição. Available from: $<$ http://www.anvisa.gov.br/servicosaude/manuais/clsi/clsi OPASM2-A8.pdf>. Accessed: Apr. 6, 2020.

CLSI (2015) Performance Standards for Antimicrobial Disk Susceptibility Tests; Approved Standard- Twelfth Edition. M02-A12, Clinical and Laboratory Standards Institute. Available from: $<$ http://www.anvisa.gov.br/servicosaude/manuais/ clsi/clsi_opasm7_a6.pdf>. Accessed: Apr. 6, 2020.

COSTA, G. M. da et al . Resistência a antimicrobianos em Staphylococcus aureus isolados de mastite em bovinos leiteiros de Minas Gerais, Brasil. Arquivos do Instituto Biológico, v.80, n.3, p.297-302, 2013. Available from: <http://www.scielo.br/ scielo.php?script $=$ sci_arttext\&pid $=$ S180816572013000300006\&1 ng=en\&nrm=iso $>$. Accessed: Nov. 20, 2020. doi: 10.1590/S180816572013000300006 .

COSTA, J. C. M. et al. Perfil de sensibilidade de células sésseis e planctônicas de Escherichia coli a antimicrobianos usados no tratamento da mastite bovina. Arquivo Brasileiro de Medicina Veterinaria e Zootecnia, v.66, n.1, p.129-136, 2014. Available from: $\quad<$ https://www.scielo.br/scielo.php?script=sci_arttext\&pi $\mathrm{d}=\mathrm{S} 0102-09352014000100019>$. Accessed: Apr. 4, 2020. doi: $10.1590 / \mathrm{S} 0102-09352014000100019$.

CARVALHO, A. S. S. et al . Susceptibility of Staphylococcus aureus isolated from raw milk to commercial antibiotics. Ciência Animal Brasileira, v.19, p.47159, 2018. Available from: <http:/ www.scielo.br/scielo.php? script $=$ sci_arttext\&pid $=\mathrm{S} 1809$ 68912018000100326\&lng $=$ en\&nrm $=$ iso $>$. Accessed: Nov. 20, 2020. doi: 10.1590/1809-6891v19e-47159.

EDWARDS-JONES, V. The benefits of silver in hygiene, personal care and healthcare. Letters in Applied Microbiology, v.49, n.2 p.147-152, 2009. Available from: <https://pubmed.ncbi.nlm.nih. gov/19515146/>. Accessed: Jun. 12, 2020. doi: 10.1111/j.1472765X.2009.02648.x.

FAYAZ, A.M.; et al.,. Biogenic synthesis of silver nanoparticles and their synergistic effect with antibiotics: a study against gram-positive and gram-negative bacteria. Nanomedicine: Nanotechnology, Biology, and Medicine, v.6. p.103-109, 2009. Available from: <https://www.sciencedirect.com/science/article/ abs/pii/S1549963409000914>. Accessed: Nov. 19, 2020. doi: 10.1016/j.nano.2009.04.006.

GALÁN, J. C. et al. Antibiotics as selectors and accelerators of diversity in the mechanisms of resistance: From the resistome to genetic plasticity in the $\beta$-lactamases world. Frontiers in Microbiology, v.4, n.FEB, p.1-17, 2013. Available from: $<$ https://www.ncbi.nlm.nih.gov/pmc/articles/PMC3567504/pdf/ fmicb-04-00009.pdf>. Accessed: Apr. 1, 2020. doi: 10.3389/ fmicb.2013.00009.

KIM, J. S. et al. Antimicrobial effects of silver nanoparticles. Nanomedicine: Nanotechnology, Biology and Medicine, v.3, p.95-101, 2007. Available from: <https://www.sciencedirect.com/ science/article/abs/pii/S1549963406003467>. Accessed: Nov. 19, 2020. doi: 10.1016/j.nano.2006.12.001.

KUMARI, H. et al. Role of Pseudomonas aeruginosa AmpR on $\beta$-lactam and non- $\beta$-lactam transient cross-resistance upon preexposure to subinhibitory concentrations of antibiotics. Journal of Medical Microbiology, v.63, n.PART 4, p.544-555, 2014. Available from: <https://www.ncbi.nlm.nih.gov/pmc/articles/ PMC3973449/pdf/544.pdf $>$. Accessed: Apr. 1, 2020. doi: 10.1099/ jmm.0.070185-0.

LASAGNO, M. et al. Screening of bacteriocin associated genes of Streptococcus uberis strains. Heliyon, v.5, n.9, p.e02393, 2019. Available from: <https://www.sciencedirect.com/science/ article/pii/S2405844019360530>. Accessed: Jun. 12, 2020. doi: 10.1016/j.heliyon.2019.e02393.

MAVRI, A.; SMOLE MOŽINA, S. Development of antimicrobial resistance in Campylobacter jejuni and Campylobacter coli adapted to biocides. International Journal of Food Microbiology, v.160, n.3, p.304-312, 2013. Available from: <https:/www.sciencedirect. com/science/article/abs/pii/S0168160512005806?via\%3Dihub>. Accessed: Apr. 1, 2020. doi: 10.1016/j.ijfoodmicro.2012.11.006.

MIRSATTARI, S. M. et al. Myoclonic status epilepticus following repeated oral ingestion of colloidal silver. Neurology, v.62, n.8, p.1408-1410, 2004. Available from: <https://www.researchgate. net/publication/8592905_Myoclonic_status_epilepticus_following repeated_oral_ingestion_of_colloidal_silver $>$. Accessed: Apr. 7, 2020. doi: $10.1212 / 01$. WN $\bar{L}$.0000120671.73335.EC.

MUSHTAQ, S. et al. Bovine mastitis: An appraisal of its alternative herbal cure. Microbial Pathogenesis, v.114, n.August 2017, p.357-361, 2018. Available from: < https://pubmed.ncbi. nlm.nih.gov/29233776/>. Accessed: Apr. 7, 2020. doi: 10.1016/j. micpath.2017.12.024.

OLIVEIRA, A. R.; et al., The influence of resveratrol adaptation on resistance to antibiotics, benzalkonium chloride, heat and acid stresses of Staphylococcus aureus and Listeria monocytogenes. Food Control, v.73, p.1420-1425, 2017. Available from: $<$ https://www.sciencedirect.com/science/article/abs/pii/ S0956713516306259>. Accessed: Apr. 1, 2020. doi: 10.1016/j. foodcont.2016.11.011. 
OTTO, M. P. et al. Effects of subinhibitory concentrations of antibiotics factor expression by community-acquired methicillinStaphylococcus aureus. Journal of Antimicrobial Chemotherapy, v.68, n.7, p.1524-1532, 2013. Available from: <https://academic. oup.com/jac/article/68/7/1524/891007>. Accessed: Apr. 6, 2020. doi: $10.1093 /$ jac/dkt073.

PAL, S.; et al.,. Does the antibacterial activity of silver nanoparticles depend on the shape of the nanoparticle? A study of the gram-negative bacterium Escherichia coli. Applied and Environmental Microbiology, v.73, n.6, p.1712-1720, 2007. Available from: $<$ https://www.researchgate.net/publication/6541826 Does_the_Antibacterial_Activity_of_Silver_Nanoparticles Depend_on_the_Shape_of_the_Nanoparticle_A_Study_of_the Gram-Negative Bacterium Escherichia coli $>$. Accessed: Apr. 4, 2020. doi: 10.1128/AEM.02218-06.

PATEL, T.; LEVITIN, A. Escherichia Coli Adaptive Resistance to Clinical Antibiotics. JSM microbiology, v.2, n.January 2014 p.1-5, 2014. Available from: <https:/www.researchgate.net/ publication/282133948_Escherichia_Coli_Adaptive_Resistance to_Clinical_Antibiotics>. Accessed: Oct. 9, 2019.

ROCH, M. et al. Exposure of Staphylococcus aureus to subinhibitory concentrations of $\beta$-lactam antibiotics induces heterogeneous vancomycin-intermediate Staphylococcus aureus. Antimicrobial Agents and Chemotherapy, v.58, n.9, p.5306-5314, 2014. Available from: $<$ https://www.ncbi.nlm.nih.gov/pmc/articles/PMC4135816/>. Accessed: Apr. 6, 2020. doi: 10.1128/AAC.02574-14.

SAEKI, E. K. et al. Mastite bovina por Staphylococcus aureus: sensibilidade às drogas antimicrobianas e ao extrato alcoólico de própolis. Acta Veterinaria Brasilica, v.5, n.3, p.284-290, 2011. Available from: $<$ https://periodicos.ufersa.edu.br/index. php/acta/article/view/2172/5019>. Accessed: Apr. 4, 2020.
SANKAR, P. New therapeuticstrategies to control and treatment of bovine mastitis. Veterinary Medicine - Open Journal, v.1, n.2, p.e7-e8, 2016. Available from: <https://openventio.org/ wp-content/uploads/2017/10/New-Therapeutic-Strategies-toControl-and-Treatment-of-Bovine-Mastitis-VMOJ-1-e004.pdf>. Accessed: Apr. 3, 2020. doi: 10.17140/VMOJ-1-e004.

SANTANA, H. F. et al. Bactericidal activity of ethanolic extracts of propolis against Staphylococcus aureus isolated from mastitic cows. World Journal of Microbiology and Biotechnology, v.28, n.2, p.485-491, 2012. Available from: <https://link.springer.com/ article/10.1007/s11274-011-0839-7>. Accessed: Apr. 7, 2020. doi: 10.1007/s11274-011-0839.

VU, X. H. et al. Synthesis and study of silver nanoparticles for antibacterial activity against Escherichia coli and Staphylococcus aureus. Advances in Natural Sciences: Nanoscience and Nanotechnology, v.9, n.2, p.025019, 2018. Available from: <https://iopscience.iop.org/ article/10.1088/2043-6254/aac58f $>$. Accessed: Nov. 22, 2020. doi: $10.1088 / 2043-6254 /$ aac58f/pdf.

XIU, Z. M.; et al., Differential effect of common ligands and molecular oxygen on antimicrobial activity of silver nanoparticles versus silver ions. Environmental Science and Technology, v.45, p.9003-9008, 2011. Available from: <https://pubs.acs.org/ doi/10.1021/es201918f>. Accessed: Nov. 19, 2020. doi: 10.1021/ es201918f.

WANG, J. et al. Propionate protects against lipopolysaccharideinduced mastitis in mice by restoring blood-milk barrier disruption and suppressing inflammatory response. Frontiers in Immunology, v.8, n.SEP, p.1-9, 2017. Available from: <https:// www.ncbi.nlm.nih.gov/pmc/articles/PMC5605562/>. Accessed: Apr. 3, 2020. doi: 10.3389/fimmu.2017.01108. 